\title{
ARAH PERENCANAAN PEMBELAJARAN BAHASA ARAB ABAD 21
}

\author{
Cahya Edi Setyawan \\ Dosen Program Studi Pendidikan Bahasa Arab \\ STAI Masjid Syuhada Yogyakarta \\ Cahya.edi24@gmail.com \\ Ahsan \\ Dosen Program Studi Pendidikan Bahasa Arab \\ Universitas Ibrahimy Situbondo \\ ahsanthayyib@gmail.com
}

\section{Abstrak}

Abad 21 telah merubah gaya hidup manusia. Abad 21 berdampak pada pendidikan dan pembelajaran. Arah baru pembelajaran menurut UNESCO yang berisi tentang 4C (Collaboration, Communication, Creativity, dan Critical Thinking) mempengaruhi arah pembelajaran bahasa Arab di Indonesia. Hal itu menjadi faktor ekternal yang mempengaruhi arah pembelajaran bahasa Arab. Ditambah lagi faktor internal pembelajaran bahasa Arab yang tak kunjung selesai yaitu 1) pola pikir yang sudah terbentuk dalam benak siswa Indonesia bahwa belajar bahasa Arab masih sulit, 2) generasi milenial di indonesia masih menganggap bahasa Arab belum begitu penting dan hanya bahasa untuk mempelajari ilmu Agama, 3) masih dalam pandangan bahwa belajar bahasa Arab adalah belajar apa itu bahasa Arab bukan belajar bagaimana berbahasa Arab, 4) habit berbahasa Arab yang masih lemah atau kurang. Maka dari itu, penulis menyajikan dan merumuskan tentang konsep bagaimana arah perencanaan pembelajaran bahasa Arab di Indonesia perspektif abad 21. Halhal yang menjadi rumusan adalah 1) konsep standar pengajaran bahasa Arab abad 21,2) konsep kebutuhan guru bahasa Arab dan pebelajar bahasa Arab abad 21,3) konsep perencanaan pengajaran bahasa Arab dalam konteks masyarakat Indonesia.

Kata Kunci: Abad 21, Pembelajaran bahasa Arab.

$$
\begin{aligned}
& \text { ملخص } \\
& \text { لقد تغير القرن الحادي والعشرون أنماط الحياة البشرية. للقرن الحادي والعشرين تأثير على التعليم } \\
& \text { والتعلم. يؤثر الاتحاه الجديد للتعلم وفقًا لليونسكو والذي يحتوي على حوالي (التعاون والتواصل } \\
& \text { والإبداع والتفكير النقدي) على ابتحاه تعلم اللغة العربية في إندونيسيا. يصبح ذلك عاملاً خارجيًا } \\
& \text { يؤثر على ابتحاه تعلم اللغة العربية. بالإضافة إلى العوامل الداخلية لتعلم اللغة العربية التي لم تنته أبلًا }
\end{aligned}
$$




$$
\begin{aligned}
& \text { هي 1) العقلية التي تكونت في عقول الطلاب الإندونيسيين بأن تعلم اللغة العربية لا يزال صعبًا، }
\end{aligned}
$$

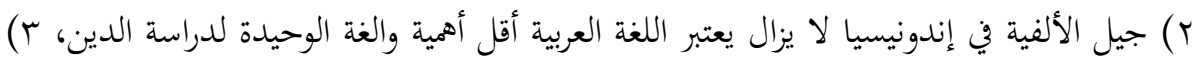

$$
\begin{aligned}
& \text { لا يزال يرى أن تعلم اللغة العربية هو تعلم ما لا يتعلم اللغة العربية كيفية التحدث باللغة العربية، } \\
& \text { ع) العادات العربية لا تزال ضعيفة أو ناقصة. لذلك، يقدم المؤلفون ويصوغون مفهوم كيف أن } \\
& \text { ابتاه التخطيط لتعلم اللغة العربية في إندونيسيا من منظور القرن الحادي والعشرين، والأشياء التي } \\
& \text { يتم صياغتها هي (1) المفاهيم القياسية لتدريس اللغة العربية في القرن الحادي والعشرين، ب ( مفهوم } \\
& \text { احتياجات معلمي اللغة العربية ومتعلميها القرن اTr، r) مفهوم التخطيط لتدريس اللغة العربية في } \\
& \text { سياق المجتمع الإندونيسي. } \\
& \text { الكلمات المفتاحية: القرن الحادي والعشرون ، تعلم اللغة العربية. }
\end{aligned}
$$

\section{A. PENDAHULUAN}

Kemajuan teknologi informasi dan komunikasi pada abad 21 telah merubah gaya hidup manusia, baik dalam bekerja, bersosialisasi, bermain maupun belajar. ${ }^{114}$ Pendidik dan peserta didik dituntut memiliki kemampuan belajar mengajar di abad 21 ini. Hal ini dikarenakan bahwa Pendidikan Nasional abad 21 bertujuan untuk mewujudkan cita-cita bangsa, yaitu masyarakat bangsa Indonesia yang sejahtera dan bahagia, dengan kedudukan yang terhormat dan setara dengan bangsa lain dalam dunia global, melalui pembentukan masyarakat yang terdiri dari sumber daya manusia yang berkualitas, yaitu pribadi yang mandiri, berkemauan dan berkemampuan untuk mewujudkan cita-cita bangsanya. ${ }^{115}$ Senada dengan itu, pendidikan abad 21 menurut PBB yaitu membangun

114 Masyarakat dan Pendidikan di Abad ke-21, Technical Cooperation Projects (JICA), diakses dari http://www.jica.go.id/project/indonesian/indonesia/0800042/materials/materi als_01.html pada tanggal 22 april 2020 pukul 23.00 WIB

115 Paradigma Pendidikan Abad 21, http://teoribagus.com/paradigmapendidikan-indonesia-abad-21, diakses pada tanggal 24 april 2020 pukul 10.00 WIB 
masyarakat berpengetahuan (knowledge-based society) yang memiliki: 1) keterampilan melek TIK dan media (ICT and media literacy skills),116 2) keterampilan berpikir kritis (critical thinking skills), 3) keterampilan memecahkan masalah (problem-solving skills), 4) keterampilan berkomunikasi efektif (effective communication skills); dan 4) keterampilan bekerjasama secara kolaboratif (collaborative skills). ${ }^{117}$

Abad 21 memberikan problem tersediri dalam dunia pendidikan. Adapun problemnya yaitu berkaitan dengan permasalahan globalisasi dan perubahan sosial. Dengan adanya globalisasi maka sekolah-sekolah di Indonesia harus mengikuti sekolah-sekolah diluar negeri secara global yaitu dengan menerapkan system managemen mutu (Quality Managemen Sistem) yang berlaku secara internasional dalam pengelolaan managemen sekolah mereka, yaitu SMM ISO 9001:2000; dan banyak diantara yang sudah menerima sertifikat ISO. ${ }^{118}$ Problem selanjutnya adalah menyangkut output pendidikan yang dituntut selalu aktual. Hal ini dipicu dengan pergeseran paradigma tentang keunggulan suatu Negara dari keunggulan komparatif (Comparative adventage) kepada keunggulan kompetitif (Competitive Advantage). ${ }^{119}$ Keunggulan komparatif bertumpu pada kekayaan sumber daya alam, sementara

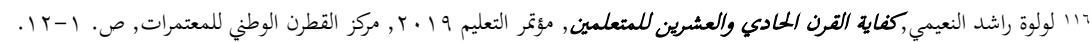

117 Nurjannah Tamil, Dinamika Pembelajaran Abad 21Bagi Daerah Terpencil dan Berkembang, Pena: Rumah Belajar Untuk Semua, diakses dari http://pena.belajar.kemdikbud.go.id pada tanggal 24 April 2020 pukul 11.00 WIB

118 Mansoer Faqih, Runtuhnya Teori Pembangunan dan Globalisasi, Yogyakarta: Insist Press dan Pustaka Pelajar, 2000 , hlm. 182

119 Kuntowijoyo, Muslim Tanpa Masjid: Esai-esai Agama, Budaya, dan Politik dalam Bingkai Strukturalisme Transendental, Bandung: Mizan, 2001, hlm. 122 
keunggulan kompetitif bertumpu pada kekayaan sumber daya manusia (SDM) yang berkualitas.

Dalam konteks pergeseran paradigma keunggulan tersebut, pendidikan nasional akan mngahadapi situasi kompetitif yang sangat tinggi, karena harus berhadapan dengan kekuatan pendidikan global. Hal ini berkaitan erat dengan kenyataan bahwa globalisasi justru melahirkan semangat cosmopolitantisme ${ }^{120}$ dimana anak-anak bangsa boleh jadi akan memilih sekolah-sekolah di luar negeri sebagai tempat pendidikan mereka karena sekolah-sekolah didalam negeri secara kompetitif under-quality (berkualitas rendah) kecenderungan ini sudah mulai terlihat pada tingkat perguruan tinggi. Problem selanjutnya adalah perubahan sosial. Dalam menghadapi perubahan sosial, pendidikan seharus melakukan inovasi-inovasi sosial secara otomatis. Fungsi pendidikan sebagai agen perubahan sisial dewasa ini justru menjadi paradoks. Kenyataan ini menunjukkan bahwa, sebagai konsekuensi dari perkembangan ilmu dan tegnologi yang demikian pesat dewasa ini, perubahan sosial berjalan lebih cepat dibandingkan upaya pembaharuan dan laju perubahan pendidikan. Sebagai akibatnya, fungsi pendidikan sebagai

120 Kosmopolitanisme adalah paham (gerakan) yang berpandangan bahwa seseorang tidak perlu mempunyai kewarganegaraan, tetapi menjadi warga dunia; paham internasionalisme. Kosmopolitanisme adalah ideologi yang menyatakan bahwa semua suku bangsa manusia merupakan satu komunitas tunggal yang memiliki moralitas yang sama. Seseorang yang memiliki pemikiran kosmopolitanisme dalam bentuk apapun disebut cosmopolitan atau kosmopolit. Komunitas cosmopolitan bisa saja didasarkan pada moralitas inklusif, hubungan ekonomi bersama, atau struktur politik yang mencangkup berbagai bangsa. Dalam komunitas kosmopolitan, orang-orang dari berbagai tempat (e.g negara-bangsa) membentuk hubungan yang saling menghargai. Kwame Anthony Appiah pernah memaparkan adanya kemungkinan komunitas cosmopolitan ketika orang-orang dari berbagai bidang (fisika, ekonomi, dll). Membina hubungan yang saling menghargai meski memiliki kepercayaan yang berbeda (agama, politik, dll). 
konservasi budaya menjadi lebih menonjol, tetapi tidak mampu mengantisipasi perubahan sosial secara akurat.

Daoed Joesof mencatat bahwa permasalahan internal pendidikan meliputi problem pada strategi, peran guru, kurikulum, system kelembagaan, sarana prasarana, managemen, anggaran operasional dan peserta didik. ${ }^{121}$ Tiga problem yang sangat krusial yaitu permasalahan system kelembagaan yaitu dualisme atau bahkan dikotomi antar pendidikan umum dan pendidikan agama yang merupakan warisan klasik yang memisahkan keduanya. ${ }^{122}$ Agar tidak ada dikotomi itu untuk menjadikan keutuhan pendidikan maka Ahmad Syafii Maarif menyarankan perlunya modal pendidikan integrative, suatu gagasan yang menyatukan kurikulum umum dan agama secara berkesinambungan. ${ }^{123}$ Guru memiliki peran penting dalam pendidikan karena ruh guru lebih penting dari komponen-komponen yang lain dalam pembelajaran. Menurut Suyanto guru yang professional harus memiliki kualifikasi dan ciri-ciri tertentu. Kualifikasi tersebut adalah dalam hal pengetahuan, sertifikasi, mampu bersaing sehat, memiliki kepribadian luhur dan prinsip etik, militansi individu, dan memiliki organisasi keprofesian. Ini artinya guru tidak bisa dijadikan moon-lighter (pekerjaan sampingan). Masih banyak guru yang statusnya masih hononer ini merupakan problem Nasional pada Abad 21 yang harus segera di atasi.

\footnotetext{
121 Joesoef, Daoed, "Pembaharuan Pendidikan dan Pikiran", dalam Sularto (ed), Masyarakat Warga dan Pergulatan Demokrasi: Antara Cita dan Fakta, Jakarta: Kompas, 2001, 210-225

122 Othman, Ali Issa, Manusia Menurut Al-Ghazali, alih bahasa Johan Smit dkk, Bandung; Pustaka, 1981, hlm. 182

123 Ahmad Syafii Maarif, "Pendidikan Islam dan Proses Pemberdayaan Umat”, Jurnal Pendidikan Islam No.2, Oktober 1996, hlm. 10-12
} 
Tuntutan global telah mengubah paradigm pembelajaran dari paradigma pembelajaran tradisional ke paradigm pembelajaran baru. Paulo Freire menyebutkan strategi pembelajaran tradisional ini sebagai strategi pelajaran dalam "gaya bank" (banking concept). Paradigma pembelajaran baru yaitu harus berpusat pada murid, menggunakan banyak media dan kolaboratif. Menurut Paulo strategi ini disebut dengan "hadap masalah" (problem posing). ${ }^{124}$ Perkembangan pembelajaran bahasa Arab di Indonesia hingga saat ini belum menyebar ke seluruh pelosok negeri, karena bahasa Arab belum menjadi kurikulum yang penting disekolah, bahasa Arab masih sekedar sebagai pelajaran pendamping disekolah-sekolah. Perkembangan bahasa Arab mengalami perkembangan yang agak menonjol dipesantren-pesantren. Hal ini dikarenakan bahasa Arab belum dianggap penting untuk dunia kerja atau kegunaan duniawi. Masyarakat Indonesai berpandangan bahwa bahasa Arab masih hanya sekedar alat untuk belajar Agama Islam, disamping itu bahasa Arab masih dianggap pelajaran yang rumit dan sulit. Generasi anak muda Indonesia saat ini masih lebih menggandrungi bahasa Inggris yang lehih pragmatis untuk kehidupan dunia.

Abad 21 merupakan era dimana anak-anak muda dinamakan generasi milenial. Generasi milenial lebih menyukai cara belajar modern seperti menggunakan tegnologi informasi seperti e-learning, aplikasi tatap muka dunia maya seperti zoom, lalu media sosial seperti whatsupp, instagram, telegram dan sebagainya. Begitu pula dengan siswa-siswa bahasa Arab masa kini Mereka lebih menyukai internet dan google sebagai gurunya.

124 Paulo Freire, Pendidikan Kaum Tertindas, Alih Bahasa Oetomo Dananjaya dkk, Jakarta: LP3ES, 2002, hlm. 51-52 
Saat ini internet dan google sudah mampu memberikan akses dan informasi secara detail dan jelas tentang kebahasaaraban. Pada era disruptive saat ini, siswa dituntut untuk melek tegnologi begitu pula dengan guru harus berinovasi dalam menggunakan media pembelajaran untuk menarik perhatian siswa, memotivasi siswa belajar dan mengikuti perkembangan zaman agar menjadi guru yang kreatif dan inovatif di era saat ini. Problem pada guru dan siswa saat ini dalam pembelajaran bahasa Arab adalah bahasa Arab itu dipelajari bukan dipraktekkan. Maka dari itu arah perencanaan pembelajaran bahasa Arab saat ini, difokuskan pada penggunaan bahasa Arab dalam berkomunikasi baik lisan maupun tulisan. Pertimbangannya adalah adanya percampuran budaya antarnegara, perkembangan dunia bisnis dan perdagangan serta perkembangan dan pengintegrasian ilmu pengetahuan.

Unsur yang terpenting dalam pembelajaran bahasa Arab adalah habit atau lingkungan berbahasa Arab. Dalam pembelajaran bahasa Arab membutuhkan lingkungan berbahasa yang baik agar mampu menciptakan suasana kebahasaan yang baik. Maka dari itu artikel ini akan menjelaskan tentang hal berikut yaitu: 1) bagaimana standar pengajaran bahasa Arab di abad 21?,2) apa yang dibutuhkan guru bahasa Arab dan pembelajar di abad 21?,3) bagaimana perencanaan pembelajaran bahasa Arab dalam konteks masyarakat Indonesia? 


\section{B. PRINSIP POKOK PEMBELAJARAN ABAD 21}

Menurut Jennifer Nichols menyederhanakan prinsip pokok pembelajaran Abad 21 ke dalam 4 prinsip pokok seperti berikut ini: 125

\section{Instruction should be student-centered يجب أن يكون التدريس متمحور)}

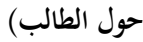

Pengembangan pembelajaran seyogyanya menggunakan pendekatan pembelajaran yang berpusat pada siswa. Siswa ditempatkan sebagai subyek pembelajaran yang secara aktif mengembangkan minat dan potensi yang dimilikinya. Siswa tidak lagi dituntut untuk mendengarkan dan menghafal materi pelajaran yang diberikan guru, tetapi berupaya mengkonstruksi pengetahuan dan keterampilannya, sesuai dengan kapasitas dan tingkat perkembangan berfikirnya, sambil diajak berkontribusi untuk memecahkan masalah-masalah nyata yang terjadi di masyarakat. Dalam pembelajaran bahasa Arab siswa tidak hanya menghafal atau mengucapkan sesuai apa yang diajarkan gurunya, namun juga siswa mampu mengungkapkan menggunakan kemampuan lisan kebahasaan mereka sendiri.

Misalnya dalam pelajaran nahwu yang membahas apa itu isim dan fiil, mereka mampu menjelaskan menggunakan bahasa Arab mereka sendiri berdasarkan apa yang telah dijelaskan oleh gurunya. Ini adalah arah pengembangan kreatifitas dan inovasi pembelajaran Abad 21. Dalam hal ini guru berperan sebagai motivator yang baik

125 Jennifer Nichols, "Four Essential Rules Of 21st Century Learning", diakses dari http://www.teachthought.com/learning/4-essential-rules-f-21stcentury-learning/ diakses pada tanggal 25 April 2020 pada pukul 16.10 WIB 
yang mampu membuat mental mahasiswa menjadi berani untuk berbicara atau mengungkapkan kebahasaan mereka. Bukan menjadi sosok guru yang menakutkan yang terbesit dibenak siswa, jika mereka mengungkapkan pikirannya ke dalam bahasa lisan, mereka takut salah. Padahal belajar yang baik adalah bukan pada penekanan salah atau benarnya, namun pada minat dan keberanian siswa untuk unjuk diri. Ini yang harus diperhatikan guru masa kini yang lebih humanis dan toleran bukan guru yang killer dan otoriter.

\section{Education should be collaborative (يب أن يكون التعليم تعاونيً)}

Siswa harus dibelajarkan untuk bisa berkolaborasi dengan orang lain. Berkolaborasi dengan orang-orang yang berbeda dalam latar budaya dan nilai-nilai yang dianutnya. Dalam menggali informasi dan membangun makna, siswa perlu didorong untuk bisa berkolaborasi dengan temanteman di kelasnya. Dalam mengerjakan suatu proyek, siswa perlu dibelajarkan bagaimana menghargai kekuatan dan talenta setiap orang serta bagaimana mengambil peran dan menyesuaikan diri secara tepat dengan mereka. Dalam pembelajaran bahasa Arab, kemampuan siswa berbeda-beda dikelas, maka guru harus mampu mengendalikan semua itu yaitui dengan cara mengkolaborasikan siswa dalam bentuk diskusi dan pemberdayaan sosial akademik dikelas yang baik. Siswa harus mampu menghargai pendapat temannya, dan berdiskusi dalam suasana belajar dan akademik yang sehat. Tidak ada unsur problem eksternal mereka yang dibawa dikelas. Sesungguhnya disini siswa diajari dan belajar bagaimana menjadi siswa yang profesional (professional student), jadi tidak cukup guru saja yang 
professional. Setiap siswa mempunyai kebahasaan yang berbeda, lisan bahasa yang berbeda, dialek yang berbeda, kemampuan struktur kebahasaan lisan yang berbeda, maka siswa harus mampu berkolaborasi satu sama lainnya agar dikelas tercipta biah lughowiyah yang baik dan dan di harapkan.

\section{Learning should have context (يجب أن يكون للتعلم سياق)}

Pembelajaran tidak akan banyak berarti jika tidak memberi dampak terhadap kehidupan siswa di luar sekolah. Oleh karena itu, materi pelajaran perlu dikaitkan dengan kehidupan sehari-hari siswa. Guru mengembangkan yang memungkinkan siswa terhubung dengan dunia nyata (real word). Guru membantu siswa agar dapat menemukan nilai, makna dan keyakinan atas apa yang sedang dipelajarinya serta dapat mengaplikasikan dalam kehidupan sehariharinya. Guru melakukan penilaian kinerja siswa yang dikaitkan dengan dunia nyata. Bahan ajar bahasa Arab saat ini sudah mengandung unsur konteks didalamnya istilah lain dalam pembelajaran bahasa Arab bisa disebut juga dengan pendekatan komunikatif. Teks-teks bahasa Arab dihubungkan dengan fakta atau kejadian yang mereka alami dalam kehidupan sehari-hari. Contohnya adalah judul-judul hiwar dalam bahan ajar selalu tentang hal-hal yang mereka alami sehari hari seperti

$$
\text { الحج وغير ذلك. }
$$

Siswa sudah harus latihan bermuhadatsah dengan temannya dalam kelas tanpa menggunakan teks tertentu namun cukup dikasih temma tertentu, lalu pembicaraan 
mengalir begitu saja antara mereka berdua. Siswa dibagi untuk berpasang-pasangan agar suasana pembicaraan lebih intens dan kondusif. Sesekali siswa diajak berhadapan dengan turis Arab atau Natif speaker dari Arab agar mereka langsung berhadapan dengan bahasa Arab nyata dari pembicara asli orang Arab. Agar mereka mendapatkan polapola dan struktur ungkapan bahasa Arab yang langsung dari orang Arab. Inilah arah dari pembelajaran dengan dunia nyata yang dimaksud.

\section{Schools should be integrated with society (دمج المدارس مع الجتمع)}

Dalam upaya mempersiapkan siswa menjadi warga negara yang bertanggung jawab, sekolah seyogyanya dapat memfasilitasi siswa untuk terlibat dalam lingkungan sosialnya. Misalnya, mengadakan kegiatan pengabdian masyarakat, dimana siswa dapat belajar mengambil peran dan melakukan aktivitas tertentu dalam lingkungan sosial. Siswa dapat dilibatkan dalam berbagai pengembangan program yang ada di masyarakat, seperti: program kesehatan, pendidikan, lingkungan hidup, dan sebagainya. Selain itu, siswa perlu diajak pula mengunjungi panti-panti asuhan untuk melatih kepekaan empati dan kepedulian sosialnya.

Dalam konteks pembelajaran bahasa Arab, maka seharusnya sekolah memberikan kurikulum pengabdian kepada masyarakat dengan segala bentuk kegiatan kebahasaaraban. Misalnya: mengadakan pelatihan bahasa Arab untuk masyarakat umum, mengadakan pelatihan kebahasaaraban untuk masyarakat yang ingin pergi umroh dan haji, mengadakan pelatihan membaca kitab kuning dasar untuk anak-anak dan remaja, mengadakan pelatihan 
atau pengajaran yang berhubungan dengan pengintegrasian bahasa Arab dan Al-quran dan sebagainya.

Intinya adalah siswa mampu terjun ke masyakarat sebagai bentuk output mereka dalam belajar di lingkungang sekolah. Hal ini agar siswa mampu berbaur dengan masyarakat dan mampu mengembangkan dan memanfaatkan keahliannya yang telah mereka pelajari di sekolah untuk orang banyak atau masyarakat yang membutuhkan. Hal ini juga mempunyai misi untuk membumikan bahasa Arab agar diterima masyarakat secara umum dan menyadarkan kepada masyarakat bahwa bahasa Arab itu penting untuk kehidupan masyarakat. Ini merupakan dampak panjang untuk masa depan siswa dan bahasa Arab itu sendiri tentang kebermanfaatannya untuk menciptakan sosio-cultural yang baik.

\section{KONSEP PEMBELAJARAN ABAD 21}

Konsep pembelajaran Abad 21, meliputi: 1) dari berpusat pada guru menuju berpusat pada siswa, 2) dari satu arah menuju interaktif, 3) dari isolasi menuju lingkungan jejaring, 126 4) dari pasif menuju aktif menyelidiki, 5) dari maya/abstrak menuju konteks dunia nyata, 6) dari pembelajaran pribadi menjadi menuju pembelajaran berbasis tim, 7) dari luas menuju perilaku khas memberdayakan kaidah keterikatan, 8) dari stimulasi rasa tunggal menuju stimulasi ke segala penjuru, 9) dari hubungan satu arah bergeser menuju kooperatif, 10) dari

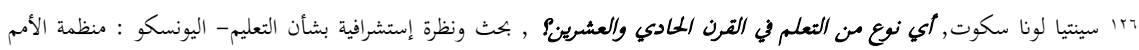

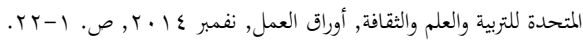


produksi massa menuju kebutuhan pelanggan, 11) dari usaha sadar tunggal menuju jama. ${ }^{127}$

Untuk mampu mengembangkan pembelajaran abad 21 ini ada beberapa hal yang penting untuk diperhatikan yaitu antara lain: 1) guru sebagai perencana pembelajaran sebagai fasilitator dan pengelola kelas maka tugas guru yang penting adalah dalam pembuatan RPP. ${ }^{128}$ RPP haruslah baik dan detil dan mampu menjelaskan semua proses yang akan terjadi dalam kelas termasuk proses penilaian dan target yang ingin dicapai. Dalam menyusun RPP, guru harus mampu mengkombinasikan antara target yang diminta dalam kurikulum nasional, pengembangan kecakapan abad 21 atau karakter nasional serta pemanfaatan teknologi dalam kelas, 2) mengutamakan berpikir tingkat tinggi (Higher Order Thinking). ${ }^{129}$ Teknologi dalam hal ini khususnya internet akan sangat memudahkan siswa untuk memperoleh informasi dan jawaban dari persoalan yang disampaikan oleh guru. Untuk permasalahan yang bersifat pengetahuan dan pemahaman bisa dicari solusinya dengan sangat mudah dan ada kecenderungan bahwa siswa hanya menjadi pengumpul informasi. Guru harus mampu memberikan tugas di tingkat aplikasi, analisa, evaluasi dan kreasi, hal ini akan mendorong siswa untuk berpikir kritis dan membaca informasi yang mereka kumpulkan sebelum menyelasikan tugas

127 Chrismi Widjajanti dkk, Peningkatan Proses Pembelajaran Dan Penilaian Pembelajaran Abad 21 Dalam Meningkatkan Kualitas Pembelajaran SMK, Direktorat Pembinaan Sekolah Menengah Kejuruan Direktorat Jenderal Pendidikan Dasar dan Menengah Kementerian Pendidikan dan Kebudayaan, Jakarta, 2018, hlm. 7-10

128 Abdul Rahim, Belajar dan Pembelajaran di Abad 21, Makalah ini disusun guna memenuhi mata perkuliahan Kurikulum dan Tegnologi Pendidikan Fakultas Ilmu Pendidikan Universitas Negeri Yogyakarta, 2016.

129 Moh. Ainin, Penilaian Dalam Pembelajaran Bahasa Arab di Madrasah atau Sekolah: HOTS, MOTS ATAU LOTS?, Prosiding Konferensi Nasional Bahasa Arab IV, Malang: 8 Oktober 2018, hlm. 156 
dari guru, 3) penerapan pola pendekatan dan model pembelajaran yang bervariasi. Beberapa pendekatan pembelajaran seperti pembelajaran berbasis proyek (Project Based Learning), pembelajaran berbasis keingintahuan (Inquiry Based Learning) serta model pembelajaran silang (jigsaw) maupun model kelas terbalik (Flipped Classroom) dapat diterapkan oleh guru untuk memperkaya pengalaman belajar siswa (Learning Experience). ${ }^{130}$

Satu hal yang perlu dipahami bahwa siswa harus mengerti dan memahami hubungan antara ilmu yang dipelajari di sekolah dengan kehidupan nyata, siswa harus mampu menerapkan ilmunya untuk mencari solusi permasalahan dalam kehidupan nyata, 4) integrasi teknologi Sekolah dimana siswa dan guru mempunyai akses teknologi yang baik harus mampu memanfaatkan teknologi dalam proses pembelajaran, siswa harus terbiasa bekerja dengan teknologi seperti layaknya orang yang bekerja. Seringkali guru mengeluhkan mengenai fasilitas teknologi yang belum mereka miliki, satu hal saja bahwa pengembangan pembelajaran abad 21 bisa dilakukan tanpa unsur teknologi, yang terpenting adalah guru yang baik yang bisa mengembangkan proses pembelajaran yang aktif dan kolaboratif, namun tentu saja guru harus berusaha untuk menguasai teknologinya terlebih dahulu. Hal yang paling mendasar yang harus diingat bahwasannya teknologi tidak akan menjadi alat bantu yang baik dan kuat apabila pola pembelajarannya masih tradisional.

130 Kemenristekdikti, Bentuk dan Metode Pembelajaran Abad 21, di unduh https://lp3m.unud.ac.id/img/admin/download/279839edac8bc5c9e515fb663e 7f5d97.pdf, pada tanggal 25 April pukul 10.20 WIB 


\section{KONSEP PEMBELAJARAN BAHASA ARAB ABAD 21}

Dalam pengajaran bahasa Arab di era abad 21 kompetensi yang sebaiknya dikuasai adalah kreativitas dan inovasi, artinya pembelajaran bahasa Arab hendaknya memunculkan sikap kreatif dan inovatif dalam memahami banyaknya perspektif budaya. Artinya dalam pembelajaran bahasa Arab harus mengedepankan unsur budaya. Belajar bahasa Arab berarti belajar baiamana pola-pola kalimat berbahasa Arab, ungkapan-ungkapan berbahasa Arab dan berbagai ekspresi-ekspresinya. Belajar bahasa Arab juga mempelajari teks-teks Arab yang menceritakan keadaan negeri Arab atau timur tengah. Sebagai contoh menceritakan sejarah awal mula turunnya Islam di mekkah dan berdirinya kabah kemudian menceritakan sejarah Al-Quds yang diceritakan dengan teks berbahasa Arab. Di samping itu perlu juga mengembangkan kompetensi berbahasa Arab dengan cara berbicara dengan teman sejawat tentang kebudayaan lokal suatu daerah, Nasionalisme dan sebagainya.

Siswa juga mampu menceritakan kehidupan sehariharinya dikampung halaman yang berbentuk tulisan. Ini arah pengembangan kreatifitas dan inovasi dalam pembelajaran bahasa Arab. Siswa juga diharapkan mampu berkomunikasi dengan lawan bicara tentang sebuah konten seperti berkomunikasi di bandara, ditempat wisata, ditempat ibadah, sekolah dan sebagainya. Maka dari itu kurikulum atau perencanaan pembelajaran bahasa Arab diarahkan pada empat hal yaitu pertama, berpikir kritis dan inovatif dalam lingkungan belajar. Kedua, mampu mengembangkan, mengimplementasikan, dan mengungkapkan ide kepada orang lain. Ketiga, bersikap terbuka dan peka terhadap perbedaan perspektif. 
Keempat, ide-ide kretaif tersebut diharapkan dapat memberikan konstribusi di tempat inovasi itu diciptakan.

Adapun berkaitan dengan tujuan dari arah perencanaan pembelajaran abad 21 adalah pada gambar berikut ini:

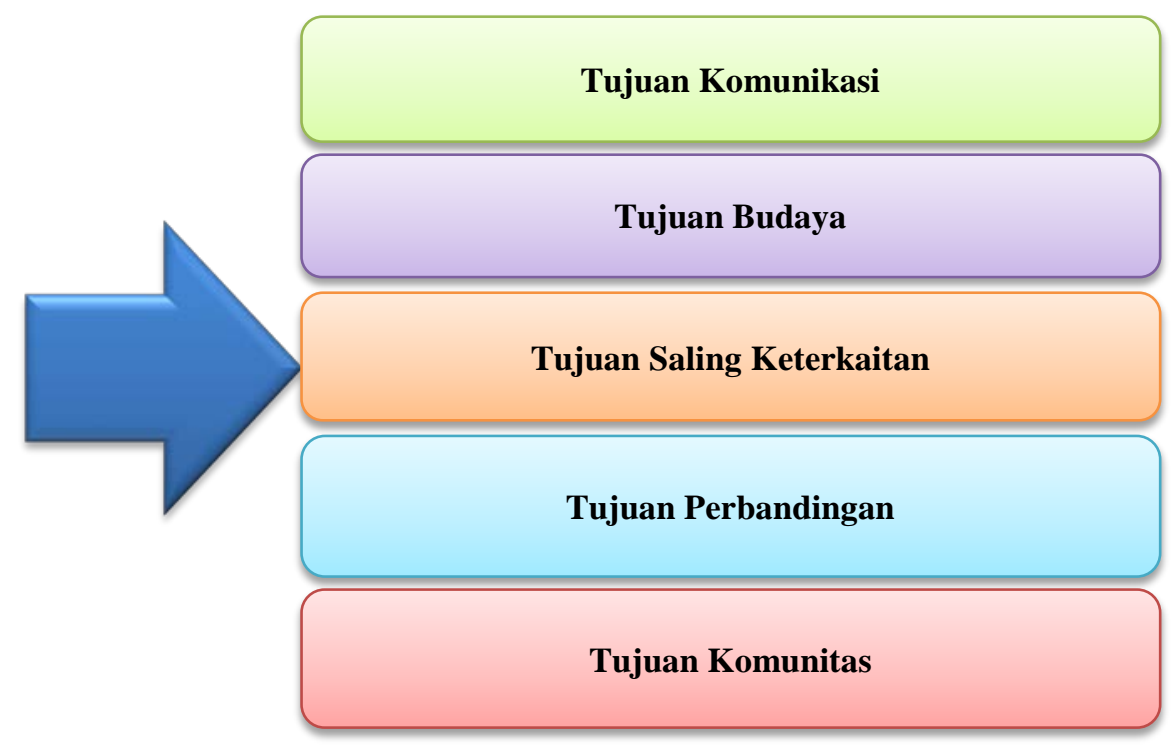

Gambar 1. Tujuan Perencanaan Pembelajaran Abad 21

Tujuan Komunikasi dapat dijabarkan sebagai berikut:

1. Kemampuan untuk menyampaikan dan menangkap makna berdasarkan tiga model komunikasi yaitu, interpersonal (antar personal), transaksi dua arah dengan orang lain, dan intrepretasi (kemampuan mengintrepretasi baik secara lisan, tulisan, maupun presentasi), serta kemampuan mempresentasikan informasi baik secara lisan dan tulis. Dalam hubungannya dengan pembelajaran bahasa Arab diharapkan siswa mampu ber-muhadatzah dengan lawan bicaranya, kemudian mampu menjelaskan materi menggunakan bahasa lisan siswa pribadi, dan mampu 
berdiskusi dalam forum kelas menggunakan bahasa Arab dengan baik.

2. Hendaknya mengajarkan empat kemahiran berbahasa Arab dalam sebuah pembelajaran secara berkesinambungan dan terintegrasi. Istilah pendekatan yang dipakai disebut Nadhariyatul Wahdah yaitu empat kemahiran berbahasa Arab diajarkan dalam satuan materi. Biasanya ditambahkan pembahasan tata bahasa (kaidah nahwu dan sharf) secara fungsional.

3. kemampuan interpersonal adalah mampu secara aktif bernegosiasi makna antar individu. Guru mengobservasi dan memonitor antar siswa satu dengan yang lainnya untuk melihat bagaimana makna dan maksud disampaikan. Selanjutnya, setiap siswa akan membuat keputusan dan klarifikasi. Dengan demikian, maka kemampuan interpersonal mempunyai peluang lebih besar untuk mencapai tujuan pembelajaran bahasa Arab. Selain itu, kemampuan interpersonal melibatkan percakapan antar siswa atau bisa juga lewat kegiatan menulis dan membaca seperti mengirim surat berbahasa Arab lewat email baik surat lamaran pekerjaan, surat rekomendasi, surat pemberitahuan kepada keluarga dan lain-lain. Menceritakan kembali makna teks Arab yang sudah dibaca dan dipahami menggunakan bahasa Arab siswa sendiri.

4. Kemampuan presentasi mengacu pada penciptaan pesan yang disampaikan oleh individu, namun individu tersebut tidak terlibat negosiasi makna secara langsung. Dengan kata lain, individu menyampaikan pengetahuan dan pemahaman mengenai suatu hal kepada orang banyak menggunakan bahasa Arab sehingga penonton mampu menangkap makna 
yang disampaikan oleh individu yang menyampaikan pesan tersebut meskipun dengan latar belakang budaya yang berbeda.

Tujuan Budaya dijabarkan sebagai berikut:

1. Belajar bahasa Arab berarti juga belajar budaya masyarakat Arab yang bahasanya dipelajari. Dengan demikian, bahasa Arab dan budaya Arab tidak bisa dipisahkan. Ketika siswa belajar bahasa Arab artinya siswa harus memahami budaya untuk menghubungkan pola-pola bahasa Arab dengan perspektif kebudayaan masyarakat setempat. Dalam pendekatan Cross Cultural Understanding ada istilah pemahaman kebudayaan untuk belajar bahasa Arab yaitu Knowledge, Awareness, Sensitivity, Competence. ${ }^{131}$

2. Pembelajar dituntut untuk mampu mengintrepetasi unsur budaya dalam teks lisan dan tulis yang mereka pelajari. Kemampuan intrepretasi bisa dilatih dengan cara membaca dan mendengar secara satu arah serta memahami isi teks menggunakan sudut pandang Arab atau sudut pandang budaya masyarakat yang mempelajari budaya asing. Dengan demikian, maka pebelajar akan kaya pengetahuan dan meningkatkan kepekaan mereka terhadap keragaman budaya.

3. Semakin banyak individu mengetahui latar belakang budaya Arab dan keragaman bahasa Arab, maka semakin mudah bagi individu tersebut mengintrepetasi budaya dari teks lisan dan tulis. Perlu diketahui bahwa kemampuan membaca dan menyimak informasi akan terus berkembang melalui

131 Cahya Edi Setyawan, Pengembangan Pembelajaran Kemahiran Berbicara Bahasa Arab Menggunakan Pendekatan Cross Cultural Understanding, Jurnal At-Ta'dib UNIDA, Vol.12, No.2 Desember 2017, hlm. 166 
dorongan dari dalam diri untuk memahami budaya dan bahasa Arab.

Tujuan saling keterkaitan sebagai berikut: Setelah siswa mempelajari bahasa target, diharapkan siswa mampu mencari informasi pengetahuan yang lain dengan bahasa target. Dengan demikian, maka kemampuan berpikir kritis akan terbangun. Diharapkan siswa mampu membandingkan penggunaan kebahasaan dalam konteks keindonesiaan dan konteks kearaban. Artinya siswa mampu membedakan dan menganalisis penggunaan kebahasaan dan perkembangannya. Lalu kemudian siswa mampu menerjemahkan baik secara lisan maupun tulisan dari bahasa Arab ke Indonesia atau Indonesia ke Arab.

Tujuan Perbandingan sebagai berikut: Sebagai siswa yang belajar bahasa dan budaya baru, siswa akan membuat perbandingan antara bahasa mereka sendiri dengan konteks budaya tempat bahasa yang dipelajari tersebut dituturkan. Dengan demikian, mereka akan paham secara mendalam mengenai konsep perbedaaan bahasa mereka dan bahasa yang mereka pelajari. Mereka juga akan memahami bagaimana bahasa yang mereka pelajari memengaruhi pandangan, praktik, dan produk masyarakat yang menggunakan bahasa itu. Keterkaitan budaya Arab dan Indonesia akan menambah khazahan keilmuan, peradaban, dan kebudayaan sehingga siswa mampu untuk mengintegrasikan kebudayaan Arab dan Indonesia secara baik dan benar untuk memperkuat keislaman dan keberislaman mereka. Artinya mampu menjaga kebudayaan Indonesia yang baik serta mampu mengambil kebudayaan Arab yang berhubungan dengan amal sholih dan Agama Islam untuk diterapkan khususnya dalam penggunaan bahasa Arab di Indonesia. 


\section{E. PERBANDINGAN ARAH PEMBELAJARAN BAHASA ARAB MODEL TRADISIONAL DAN KEKINIAN}

Untuk mengetahui unsur -unsur perbandingan antara arah pembelajaran bahasa Arab tradisional dan masa kini bisa dilihat sebagai berikut:

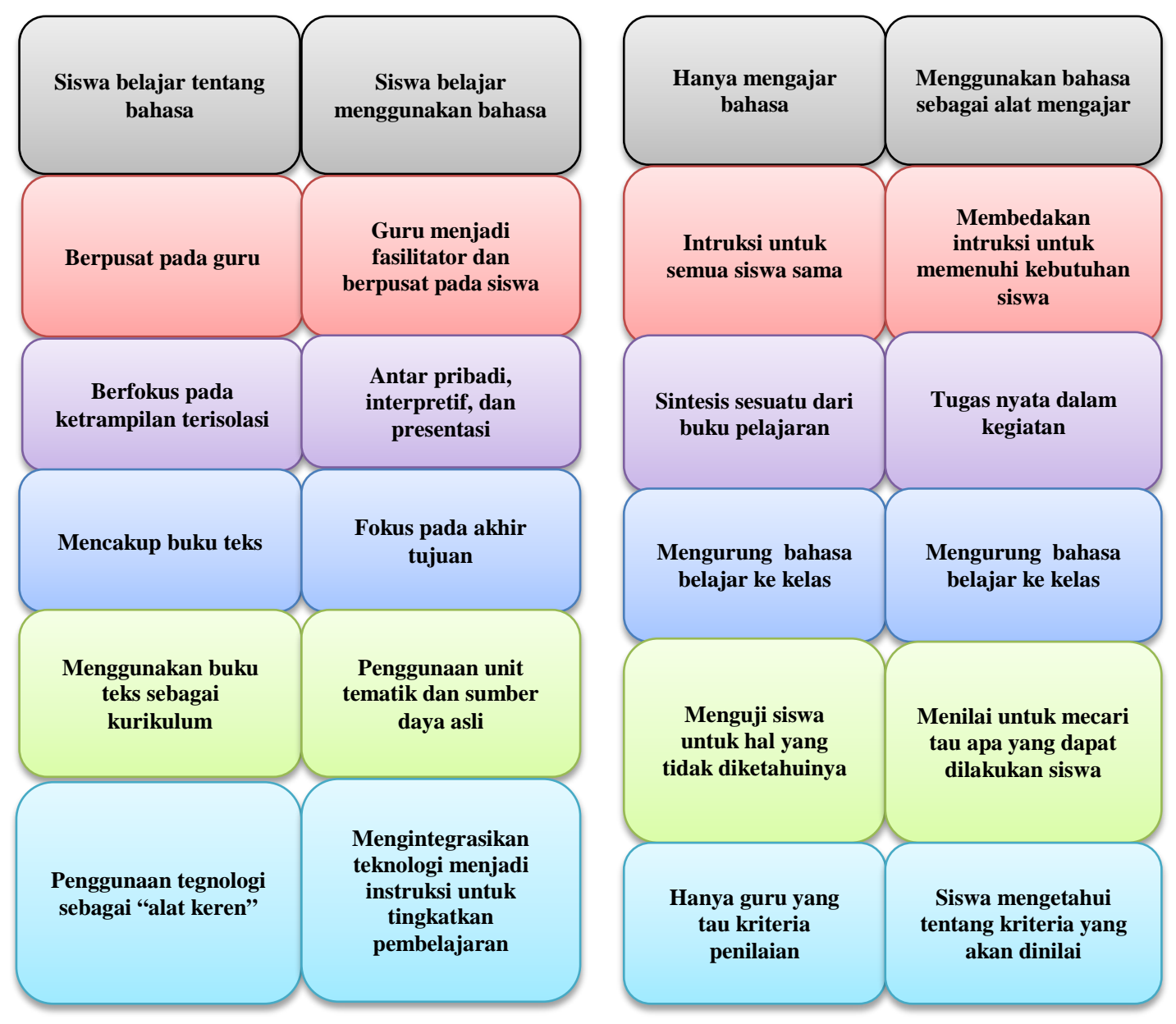

Gambar 2. Model Pembelajaran bahasa Arab tradisional dan Kekinian 


\section{F. APA KEBUTUHAN PENGAJAR BAHASA ARAB ABAD 21?}

Sebenarnya, yang dibutuhkan oleh seorang guru adalah terpapar jelas dalam kompetensi guru. Setidaknya guru bahasa Arab tidak hanya terfokus pada penerapan suatu teori pada tujuan tertentu. Namun seorang guru harus mampu mengajarkan bagaimana mempraktekkan bahasa Arab atau implementasi bahasa Arab. Masalah teori, metode, dan strategi guru mampu mengembangkan sesuai kondisi lingkungan dan siswanya. Di dalam pembelajaran guru mampu mengkolaborasikan teori-teori pembelajaran bahasa Arab serta mengembangkannya. Seorang guru bahasa Arab setidaknya memilik ruh dan lisan berbahasa Arab yang bagus, meskipun tidak sebagus native speaker setidaknya guru menggunakan bahasa Arab untuk mengajar dan berkomunikasi dengan siswanya. Ruh yang bagus artinya adalah memegang teguh dalam berbahasa Arab baiki didalam kelas maupun dalam kelas.

Guru bahasa Arab harus memahami kebutuhan siswanya akan belajar bahasa Arab. Dalam hal ini guru menerapkan dengan cara problem basic learning. Tanyakan kepada siswa tentang apa yang dibutuhkan untuk belajar bahasa Arab, tanyakan juga alasan kenapa belajar bahasa Arab, tanyakan juga untuk apa belajar bahasa Arab, lalu bagaimana mempelajarinya, jika butuh mereka bantuan dalam proses belajar maka fungsi guru sebagai fasilitator harus dimaksimalkan. Guru yang baik harus mampu mengembangankan kebahasaan siswa dan mampu mengarahkan siswanya untuk memecahkan problemnya sendiri dalam berbahasa Arab. Guru bahasa Arab harus memiliki personality (الشخصية), dan leadership (القيادة) kebahasaaan yang bagus sehingga mampu membangkitkan gairah dan antusias 
siswanya dalam berbahasa Arab. Dan satu hal lagi yang paling penting dalam pembelajaran bahasa Arab di era kekinian guru harus mampu menggunakan tegnologi dengan baik. Maka dari itu menurut penganut teori post method ,bahwa guru bahasa di abad 21 harus memahami tiga unsur yaitu kekhususan (parcularity), kepraktisan (practically), dan kemungkinan (possibility). Kekhususan yang dimaksud adalah kompetensinya dan kepribadian kebahasaanya. Kepraktisan adalah cara mengajar, cara berkomunikasi dengan siswa, cara bersosialisasi dengan siswa serta mengkondisikan proses pembelajaran. Kemungkinan adalah memiliki skill akademik yang bagus yang mampu menjadi fasilitator yang solutif dalam problem belajar, Profesional dalam mengajar dan berbahasa Arab, dan mampu membangkitkan minat dan bakat siswa dalam berbahasa Arab.
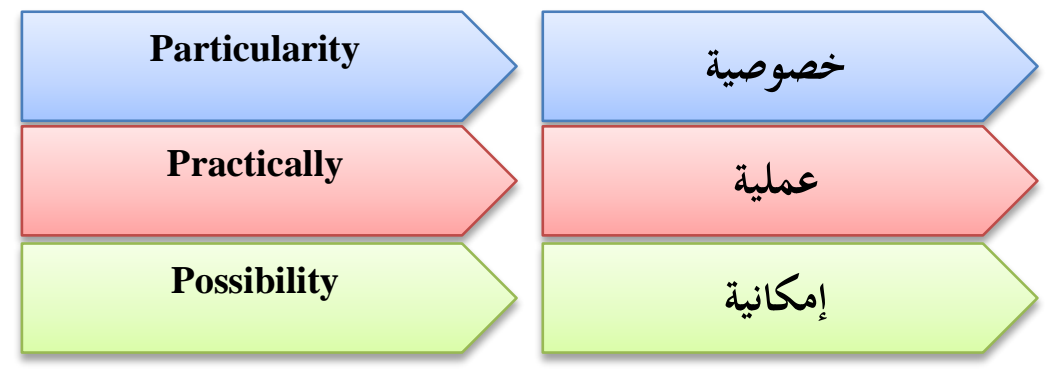

Gambar 3. Tiga Unsur Kekhususan Guru Bahasa Arab Abad 21

\section{G. APA KEBUTUHAN PEMBELAJAR BAHASA ARAB ABAD 21?}

Penguasaan terhadap teknologi. belajar dengan menggunakan internet dan teknologi lain yang mendukung kemampuan akademik dan pembelajaran bahasa Arab dalam pengembangan sosial, kepercayaan diri, dan keberanian setiap individu. Siswa harus memiliki "Self Awarenes" yaitu kesadaran diri akan pentingnya bahasa Arab pada era 21 ini, di mana bahasa Arab sudah menjadi bahasa yang penting untuk segala 
bidang khusunya di bidang pendidikan, politik, dan ekonomi. Kenapa? Karena bahasa Arab saat ini sudah mampu bersanding dengan bahasa Inggris dan lainnya yang mana merupakan bahasa Internasional. Siswa pembelajar bahasa Arab pada abad ke 21 dituntut untuk menguasai kompetensi-kompetensi yang sudah disebutkan pada standar pengajaran bahasa pada abad ke 21 dan fleksibilitas sangat dibutuhkan untuk kesuksesan pembelajaran abad ke 21. Siswa pembelajar bahasa Arab abad 21 setidaknya memiliki tiga hal yaitu keberanian unjuk diri dikelas (courage to show themselves in class), berjiwa sosial tinggi (high social minded), kesadaran diri akan pentingnya bahasa Arab (self awareness of the importance of Arabic).

\section{H. PERENCANAAN PEMBELAJARAN BAHASA ARAB ABAD 21}

1. Tema-tema Interdisipliner

Pada era abad ke-21, pengajaran bahasa Arab sebaiknya mengacu pada tematik yang artinya siswa mempelajari tema tertentu, namun di dalamnya memuat unsur-unsur kebahasaan. Dengan demikian, pengajaran bahasa Arab menjadi lebih bermakna. Salah satu contoh tema interdisipliner bisa memuat materi teknologi, biologi, lingkungan keseharian, kesehatan, kebudayaan, perkomputeran, internet, media sosial, politik dan lain sebagainya. Namun, fokusnya adalah belajar bahasa melalui konten tersebut. Sehingga, tidak hanya berfokus mempelajari tata bahasa atau aspek kebahasaan secara terpisah melainkan menjadi satu kesatuan. Tema-tema berisi teks cerita atau percakapan (hiwar) tentang hal-hal diatas. Sehingga siswa memungkinkan untuk belajar konten interdisipliner yaitu cerita yang berisi konten eksternal 
bahasa Arab namun memuat kosakata-kosakata bahasa Arab dan pola-pola kalimat tentang bahasa Arab dalam bidang tersebut. Banyak pembentukan kosakata-kosakata baru dan pola-pola kalimat dan ungkapan baru dalam bahasa Arab. Hal ini perlu di diketahui oleh siswa bahasa Arab. Banyak kosakata dan ungkapan yang terbentuk oleh masyarakat bahasa. Bahasa itu terbentuk oleh perkembangan ilmu pengetahuan baru.

2. Pembelajaran Otentik

Pembelajaran otentik sebagai pembelajaran yang berfokus pada dunia nyata, masalah kompleks, dan mencari pemecahan masalah, menggunakan latihan-tatihan berupa bermain peran, aktivitas-aktivitas berdasarkan pemecahan masalah, studi kasus, dan partisipasi dalam komunikasi virtual. Dengan demikian, maka pembelajaran otentik sama dengan aplikasi ilmu terhadap dunia nyata dan melibatkan ilmu-ilmu interdisipliner. Siswa yang terlibat dalam aktivitas pembelajaran otentik harus menguasai macam-macam keahlian portable (portable skills) yang mencangkup, (1) memberi penilaian untuk membedakan informasi yang terpercaya dan tidak terpercaya, (2) kesabaran untuk beragumen, kemampuan sintetis untuk mengingat polapola konteks tidak familiar, dan (4) fleksibilitas untuk bekerja antar ilmu disipliner dan batas budaya untuk membuat solusi inovasi.

Dalam pembelajaran bahasa Arab siswa diarahkan untuk belajar secara nyata artinya materi-materi berisi tentang kehidupan yang dialami siswa. Bercakap-cakap secara alami baik dengan teman sejawat ataupun dengan native speaker dari Arab. Siswa harus mampu membuat 
percakapan sendiri menurut konten atau tema yang di sukai. Siswa harus mampu membuat teks berbahasa Arab. Siswa harus mampu membuat surat-menyurat berbahasa Arab. Siswa harus memahami administrasi berbahasa Arab. Siswa harus mampu bercerita secara lisan maupun tulisan bahasa Arab. Siswa harus mampu berpidato, berperan sebagai presenter dan pengamat ekonomi, politik, sosial yang semuanya berbahasa Arab.

3. Guru dan Siswa Terbuka pada Perkembangan Teknologi

Siswa pembelajar pada era abad ke-21 dimudahkan dengan kemajuan teknologi yang canggih. Dengan demikian pebelajar bahasa tidak hanya bisa belajar bahasa dalam lingkungan formal sekolah saja, melainkan bisa belajar dimana saja. Selain itu, belajar bahasa juga dapat dilakukan online. Sekarang, banyak tersedia website-website yang memuat segala bentuk media pembelajaran dalam bahasa Arab. Sebagai pebelajar bahasa hendaknya terbuka atau aktif mencari bahan-bahan pembelajaran bahasa dari sumber internet. Sebagai seorang guru di era abad ke 21, hendaknya juga lebih fleksible pada perubahan perkembangan jaman. Materi ajar yang tersedia sekarang tidak hanya terpaku pada buku teks, melainkan banyak dari berbagai sumber, salah satunya internet. Dalam konteks masyarakat Indonesia yang terdiri dari beragam suku, hendaknya kurikulum standar dari pemerintah hanya sebagai acuan atau standar. Selanjutnya, untuk pengaplikasiannya, pembelajaran bahasa Arab sebaiknya disesuaikan dengan budaya masyarakat setempat. Karena belajar bahasa Arab juga mempelajari tentang budaya. Jika topik tentang budaya disesuikan dengan lokasi pembelajar, 
maka akan lebih mudah bagi anak untuk memahami konten dalam mempelajari bahasa Arab.

\section{KESIMPULAN}

Arah perencanaan pembelajaran bahasa Arab abad 21 mencangkup tiga hal penting yaitu konsep standar pengajaran bahasa Arab di Abad 21, konsep kebutuhan guru dan siswa pembelajar bahasa Arab di Abad 21, konsep perencanaan pembelajaran bahasa Arab di Abad 21. Standar pengajaran pengajaran bahasa Arab di Abad 21 mengarah kepada pembelajaran menurut UNESCO yaitu 4C (Collaboration, Communication, Creativity, dan Critical Thinking). Guru bahasa Arab di Abad 21 setidaknya memiliki dan memahami tiga hal yaitu Particularity, Practically, dan Possibility. Siswa pembelajar bahasa Arab setidaknya memiliki tiga hal yaitu keberanian unjuk diri dikelas (courage to show themselves in class), berjiwa sosial tinggi (high social minded), kesadaran diri akan pentingnya bahasa Arab (self awareness of the importance of Arabic). Adapun perencanaan pembelajaran bahasa Arab memuat tentang tema-tema interdisipliner, dan pembelajaran otentik. 


\section{DAFTAR PUSTAKA}

Ainin M, Penilaian Dalam Pembelajaran Bahasa Arab di Madrasah atau Sekolah: HOTS, MOTS ATAU LOTS?, Prosiding Konferensi Nasional Bahasa Arab IV, Malang: 8 Oktober 2018.

Edi Setyawan C, Pengembangan Pembelajaran Kemahiran Berbicara Bahasa Arab Menggunakan Pendekatan Cross Cultural Understanding, Jurnal At-Ta'dib UNIDA, Vol.12, No.2 Desember 2017.

Faqih M, Runtuhnya Teori Pembangunan dan Globalisasi, Yogyakarta: Insist Press dan Pustaka Pelajar, 2000.

Joesoef, Daoed, "Pembaharuan Pendidikan dan Pikiran", dalam Sularto (ed), Masyarakat Warga dan Pergulatan Demokrasi: Antara Cita dan Fakta, Jakarta: Kompas, 2001.

Kuntowijoyo, Muslim Tanpa Masjid: Esai-esai Agama, Budaya, dan Politik dalam Bingkai Strukturalisme Transendental, Bandung: Mizan, 2001.

Maarif, Ahmad Syafii, "Pendidikan Islam dan Proses Pemberdayaan Umat”, Jurnal Pendidikan Islam, No.2, Oktober 1996.

Othman, Ali Issa, Manusia Menurut Al-Ghazali, alih bahasa Johan Smit dkk, Bandung; Pustaka, 1981.

Paulo Freire, Pendidikan Kaum Tertindas, Alih Bahasa Oetomo Dananjaya dkk, Jakarta: LP3ES, 2002.

Rahim A, Belajar dan Pembelajaran di Abad 21, Makalah ini disusun guna memenuhi mata perkuliahan Kurikulum dan Tegnologi Pendidikan Fakultas Ilmu Pendidikan Universitas Negeri Yogyakarta, 2016.

Widjajanti C dkk, Peningkatan Proses Pembelajaran Dan Penilaian Pembelajaran Abad 21 Dalam Meningkatkan Kualitas Pembelajaran SMK, Direktorat Pembinaan Sekolah Menengah Kejuruan Direktorat Jenderal Pendidikan Dasar dan Menengah Kementerian Pendidikan dan Kebudayaan, Jakarta, 2018. 
Cahya Edi Setyawan, Ahsan : Arah Perencanaan Pembelajaran Bahasa Arab Abad 21

سينتيا لونا سكوت, أي نوع من التعلم في القرن الحادي والعشرين؟ , بحث ونظرة إستشرافية بشأن

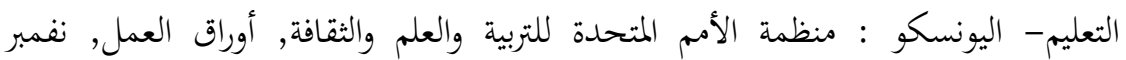
.$r \cdot 1 \varepsilon$

لولوة راشد النعيمي,كفاية القرن الحادي والعشرين للمتعلمين, مؤتمر التعليم 9 اــا مركز القطرن

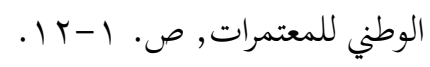

